\title{
The prevalence narcotics trade in the world market and the associated challenges
}

\author{
Khaled A. Alasmari \\ Academy of Economic Studies, Romania \\ haql@hotmail.com
}

Abstract. The use of narcotics has been one of the biggest problems the contemporary governments have had to deal with amidst so much resistance and adamancy. This article would focus on the narcotic drug network in the world. This would be done by examining the major areas in the world where the illicit trade is most prevalent. Through the analysis of the major targets, destinations, and sources of these drugs, this article would be able to uncover the size of the narcotic trade in the world today. This would involve discussing the associated behaviors and effects on the health of an individual who uses these drugs.

Received:

June, 2013

1st Revision:

September, 2013

Accepted:

October, 2013

The narcotic trade, with its prevalence, has affected a wide continuum of people in the society; the youth, the old, women, and children. The youth have been the most contributors in the illicit trade, and as this article uncovers, a big percentage of the drug users and traffickers are young people. This article would critically examine the expanse of the narcotic business in the world, and the contributing factors to this prevalence. Further, it would address the legislation that has been enacted by governments in an effort to curb this vice, and particularly focus on the flaws in the regulations put in place by governments to deal with narcotic trade.

This article would discuss the prevalence of psychotropic substances and narcotic drugs, which is evidently the world's major concern today since the whole business has brought about a wide variety of devastating effects. This can be alluded to a few years back when drug abuse and trafficking was only a problem associated with few countries, but today, the whole world has found itself right in the middle of this vice.

Keywords: narcotics drug network, prevalance of narcotics trade, illicit trade, psychotropic substances, Money laundering.

JEL classification: K49.

\section{INTRODUCTION}

Some of the things that are crystal clear about the narcotic business is that it has infiltrated the society, and its consuming the members of the society by hampering their functionality and corrupting their health. 
The prevalence of this illicit trade has been a major source of concern since its effects have cut deep into society and have hurt society in the most painful manner. The quick spread of the narcotic trade in the world can be attributed to the vulnerability of some groups in the community like the youth. The youth are a vulnerable lot, considering the fact that a big percentage of them are faced by social economic challenges. These challenges include unemployment and lack of adequate education and they make this group vulnerable and susceptible to the temptation of drug use and trading as a comfort zone United States, \& Halpern, S. (1972).

The drug trafficking business and the traffickers lure followers with a notion that the business would make them a quick dollar besides making the high. Being intoxicated is believed by many drug users as one of the most effective ways of running away from the challenges of the real world. The challenges and the economic hardships all over the world have been the main cause of increased drug use and trafficking in the world besides minor causes like peer influence and moral degradation. Unfortunately, the illicit trafficking of psychotropic substances and narcotic drugs generates a lot of funds. Therefore, the criminal groups would become millionaires who give the money made from drug trafficking a licit source, which would damage the national economies both in the short run and the long run.

The prevalence of this business can be attributed to many factors besides the socio economic factors. The techniques used by these traffickers have been growing un terms of sophistication, where different techniques that tend to improve and change all the time according to the countermeasures put in place by law enforcing agencies. The technicality that arises in an attempt to stop drug traffickers is that these traders do not use a particular or specific means of transporting their cargo, which makes the process of stopping them even more challenging, Steinberg, D. I. (2010).

Trafficking of psychotropic and narcotic drugs has proved to be one of the most predicate offences that the world faces today. This predicate offense generates large amounts of money, which is later laundered by money launderers. These funds are not taken to banks since the culprits fear to arouse any suspicion that might lead to their apprehension. Money launderers, therefore, opt for sectors that are not strictly supervised, these sectors conceal illegally generated funds among the licit funds. The whole process covers the offenders and helps them to remain stealth from the law enforcement agencies.

This article recommends that relevant stakeholders should do all it takes to ensure that the bodies responsible for combating illicit trafficking are enhanced. This can be done by ensuring that the general directorate is commensurate with the seriousness or magnitude of the problem and the probable risk that the country is likely to face as a result of this trade. Coming up with specialized divisions that could help curb the money laundering menace, is yet another means of stopping the narcotic business that has wrecked the world like a plague. This is because the money laundering business happens inside the bodies designed to deal with illicit trafficking of narcotics and psychotropic substances, Steinberg, D. I. (2010). The specialized divisions would work to ensure that investigations concerning narcotic drugs are done parallel to the other money laundering offences.

Despite the fact that money laundering and illicit trafficking of narcotics in the world affect literary every country in the world, some countries feel the pinch just more painfully than the others. These are countries where the prevalence drug trafficking has reached chronic levels. For such countries, this article recommends that international organizations have to play an important role of ensuring that they provide the necessary support and the valuable support to these countries, in their effort to combat the illicit trafficking of narcotics and psychotropic substances. Raising of awareness is one of the chief mechanisms of dealing with this problem, where the community has all the knowledge about the illegality of abusing narcotics and the dangers associated with the whole business. 
Illicit trafficking of psychotropic substances and narcotics has been top of the United Nations' agenda in collaboration with international cooperation. However, very little has been achieved so far in terms of curbing this problem. The threat to public health posed by narcotics and the expansive nature of this illicit trade has threatened the safety and well-being of humanity, which concerns majorly the youths. The whole narcotic business has undermined the socio-economic and political stability of many countries besides threatening the sovereignty of these countries. The CND (the commission on narcotic drugs) and UNODC (the United Nations Office on Drugs and Crime) have worked to their level best to ensure that the effects of the expanded narcotic trade do not hurt countries and their citizens. Despite the obvious challenges, these bodies have targeted to substantially reduce the prevalence of this trade.

As mentioned before, drugs and narcotics have devastating effects ranging from health issues to socio economic issues, making this trade one of the worst world threats today. This is the reason why most of the countries have gone out of their ways to ensure that this problem is curbed at all levels.

\section{FACTORS CONTRIBUTING TO THE SPREAD OF NARCOTIC TRADE IN THE WORLD}

The narcotic trade is on a rampant growth with drug cartel spreading out of Mexico and other countries in South America to the rest of the world. The Middle East and Africa are some of the region, which have fallen prey of the drug trafficking menace in the recent past. With the many challenges in these regions, both social and economical, drug trafficking has found a platform to exploit the new market "niches". Poor people, youth, and children have suffered the most in this process, and that is the reason why governments have been compelled to take action to curb this problem.

There are various factors that have influenced the persisted prevalence of this trade in the aforementioned regions besides the other regions harboring large drug cartels. This article would carry out a stepwise analysis of the factors influencing narcotic trade. The article would further examine why the efforts to stop narcotic trade in these regions have always been frustrated despite the commitment by the various stakeholders.

\section{POVERTY}

Poverty has been a significant contributory factor in the spread and expansion of narcotics in the world, especially in Asian and African countries. The United Nations has raised concern on the continued rise of the use of narcotics in African countries, Asian countries and other poverty-stricken areas of the world. Research suggests that there is a strong correlation between poverty and drug and substance abuse. People who are said to be in poverty are those who are unable to afford most of the basic commodities, and those who suffer inequalities with regard to the social and economic circumstances that they are in. These people are considered susceptible and vulnerable in many aspects, which explains why most of these people end up in desperate positions.

Since people in poverty might not have proper shelter, or might be living in the streets out of lack of finances to pay for anything, drug peddlers see a window of opportunity and recruit these people into their cartels and networks. The susceptibility of these poor people makes them view any opportunity to make some money as a lucrative one. Joining drug networks, therefore, becomes the best idea at the time, and before these individual know it, they would have become hardcore criminals who would not stop at anything to make an extra quick dollar. A significant part of these poor people is intelligent and innovative people. These people would, therefore, transfer these skills to the narcotics business making the whole group an elite 
lot, making it hard for the law enforcement agencies to stop them. This explains, partly, why the narcotic trade in the world is getting sophisticated by the day.

Despite the fact that the drug users and traffickers might understand the risk factors associated with using and trafficking drugs, they go on with the trade. The poor people are only on the front, doing dangerous transactions, which leaves them using the drugs themselves out of the tension involved while others simply end up dead. The poor upbringing of children, where children in most poor families have complicated upbringings is also a contributory factor to the prevalence of the narcotic trade in the world. These people have literary few to no options when it comes to whether they should stay in these cartels and networks or not.

The exploitation and human trafficking menace is one of a poverty-associated factor, where the trafficked women, most of them under age, are used as channels of distribution. The assumption of innocence that most of these girls carry with them enables them to go past security undetected. Literary almost everyone is a suspect of narcotic drug trafficking, a fact that the authorities are yet to embrace. Poverty stricken streets have become dungeons and hubs that harbor the people that understand no other language, apart from the language of drug trafficking. Abuse of trafficking of drugs like cocaine is now done in the rural areas of many nations. This is an indication that no one is really safe from drug traffickers and peddlers. In countries where cases of human trafficking is rampant, like Nigeria and Russia, the issue of narcotic trade is a common thing. This explains why the narcotic trade has wrecked literary the whole world as opposed to a few years back when only selected countries were affected.

\section{GOVERNMENT CORRUPTION AND LOW LEVELS OF EDUCATION}

Some governments in Africa and Latin America have shown complacency in the illicit trade of narcotics. These governments have chosen to stay on the wrong side of international law, by accomplices of drug cartels and networks. These governments do this for various reasons, the major one being that individuals in superior positions exploit this as an opportunity to make some personal gains.

The government, any government, is the last line of defense of its citizens. This is to say that the government is solely responsible for the well-being of its citizens, be it their health or their social well being. In the case where the government is the perpetrator, it is the hardest paradox that one can never solve except the government itself. The narcotic trade is expanding rampantly because of the aforementioned governments. The drug traffickers and traders are allowed to move unrestricted throughout the country and sometimes across the borders under the protection of public and government officials. This shows the stalemate the United Nations and the international community faces in their fight to stop narcotic businesses.

The government's complacency and technically legalizing activities associated with drug trafficking has crippled the efforts of other legitimate governments to curb this vice, and condemned the poor victims of this business to uncertain eventualities. The overall assessment of how fast the narcotic business is gaining ground, according to research, will soon make it a world disaster, a disaster that our own existing governments have created. In Honduras and Bolivia, for example, the corrupt governments rose to power in the late 1970s and early 1980s. In Panama, a long term and hardened criminal and drug trafficker Manuel Noriega became the president of that country between 1983 and 1989. His presidency was backed by the United States through the CIA. This indicates that even the world's largest democracies like the United States have multiple moles in government who are complacent with the narcotic business.

With such enormous support, the business had strong foundations in the 1980s and has been growing exponentially ever since, in the sense that, today, the narcotic business is not far away from being termed a world disaster. In Haiti in the 1990s, the intelligence agencies, the military and other law enforcement 
agencies were actively involved in drug trafficking. This are simply some of the few examples from the many governments that have been accomplices to the narcotic business, with one of the most interesting cases involving the United States' Los Angeles Police department. The LAPD was actively involved in the narcotic business in the 1990s to date, which forced the federal government to intervene by introducing a consent decree. This was due to the rampant corruption and abuse of power including extra judicial killings, but most of all, the police department's active involvement in trafficking of narcotics and aiding the peddlers to carry out their business with minimum interference.

This gives a fair picture of just how large the narcotic trade is in the world today. The traffickers have infiltrated almost all sectors of the economy and all the law enforcement agencies, with the CIA being one of those elite law enforcement agencies that have been compromised. This is the reason why the narcotic trade is expanding fast and getting more and more unstoppable since the personalities involved hold high status in the society and politics.

Low levels of education, on the other hand, contribute to the prevalence of the narcotic trade in various ways. This is because low education is associated with poverty and little awareness. Most uneducated people are poor, and as mentioned earlier, poverty is a major contributory factor to the involvement of people in the narcotic business. In countries like Afghanistan, Nigeria, and other countries in Africa and Asia, drug trafficking has been associated with illiteracy and lack of adequate education. People who are uneducated are less likely to secure jobs. These people fall prey of drug traffickers who would promise them jobs and a means of earning a living. The narcotic business has exploited all categories of people, where the poor have been recruited to perform most of the groundwork while those in power are used as leverage and a means of authorization to move around the country and the world.

Education creates awareness, and through education, many governments are attempting to reach their people by sensitizing them about the dangers associated with drug abuse. Through rehabilitation centers, the stakeholders would be in a position to educate people on the dangers associated with the use of narcotics. Therefore, lack of education would mean a big number of people would find themselves victim of this vice, and vulnerable to exploitation by drug cartels and networks, Angel-Ajani, A. (2010).

Low levels of education, therefore, are also a contributory factor to the expanding narcotic trade in the world. People who are less educated become frustrated due to the fact that they cannot secure decent jobs, which leaves them few options.

\section{DRUG CONTROL ACCOMPLISHMENTS, POLICIES, AND TRENDS}

Some of the countries that have made significant steps towards curbing the drug trafficking menace are the United States and Honduras. In the year 2011, the two countries came up with a mechanism to reduce the pace at which drug cartels and networks were growing in within their borders and beyond. This was done by building the Honduran institutional capacity to probe, prosecute, and adjudicate all acts of crime, drug trafficking inclusive. Honduras has been for a long time, a drug trafficking hub, with its leaders being corrupt and complacent with the narcotics business, Mccoy, A. W., \& Block, A. A. (1992).

Honduras has taken several strategic steps towards curbing of this vice, and the fruits of this effort are forthcoming. The security tax passed in June 2011 by the Honduran government was one of the government's boldest steps, amidst the strong opposition from the private sector. This meant that the government was more than willing and committed to enforce fiscal discipline in support of its objectives concerning security matters and the welfare of its people. Despite the many challenges that faced this policy, including 
failure to immediately disburse the funds, it a promising effort for the Honduran government considering where the country has come from in terms of security and drug trafficking.

The United States, on the other hand, has worked and led by example to ensure that all its borders are sealed for any drug traffickers, cartels, and networks. The drug trafficking issue and the prevalence of the trade in the neighboring México has been one of the United States main challenge infighting this vice. The drug trafficking scandals are still prevalent in the United States, some law enforcement agencies, according to research, have exhibited some degree of complacency, but this been well taken care of by the government. The infamous accusations about the LAPD and other law enforcement agencies being accomplices in the drug trafficking menace has been taken care of to some degree. The United States government is obviously committed to ensure that drug cartels do not have room in the country United States (2007).

The case example in this article as stated earlier is Honduras, which has come from an extremely delicate narcotic situation with corrupt leaders, to a more stable with leaders who have a vision, and determination to curb drug trafficking. The US has helped the country improve its investigative capacity by coming up with programs that aid training police, judges, and prosecutors. This is besides several courses of criminology, passport fraud prevention, and anti money laundering in their learning institutions. On an overall scale, Honduras and the United States are representations of the efforts of many other world countries to curb the narcotic trade.

Other countries in Africa where human trafficking is prevalent have attempted to stop the modern day slavery as a preliminary step in curbing drug trafficking. This is because the two vices go hand in hand, and in most occasions, criminals who traffic human beings traffic narcotics too.

International bodies and organizations like UN Convention against Corruption have given many countries the support they require to ensure that narcotic trade is stopped. The United Nations knows the fact that the size of drug cartels and the notoriety of the narcotic trade in the world has reached an alarming level. This is why unilateral efforts would not take this fight any further than now, prompting action by even more specialized bodies like the UN Convention against Transnational Organized Crime. This body goes a long way to ensure that organized crime like the drug cartels have little or no breathing space in the modern society.

\section{EXTENT OF DRUG USE ON YOUNG PEOPLE FROM A GLOBAL PERSPECTIVE}

One of the growing concerns that have gripped the attention of all governments and most charity organizations is the targeting of youth and children as the new market for the illicit drug industry. The trade market value for both legal and illegal drugs globally has been valued at over 400 billion dollars. Children, as well as the youth, are a big part of the whole illegal drug network, which has become more sophisticated with time, and is spread all over the world. Funded by extremely rich and well protected drug lords, the children, especially runaways or those living on the street are left vulnerable to this trade. Either as users or peddlers, children are victims and sometimes have no choice but to cooperate with these gangs, failure to which there would be a lot of consequences, Angel-Ajani, A. (2010).

World statistics and population growth trends show that there would be a significant shift in the number of youth and children all over the world. Estimates indicate that, between the year 2000 and 2050, youth and children aged between 10 to 19 years of age would decrease in some parts of Asia and Europe, including Norway, China, Sweden and Australia. However, contrary to the declining effect that would be witnessed in some parts of Asia and Europe, Africa is on the rise. A growth rate of about 3\% annually would see the age group grow to about 258 million children, just by the year 2025. Areas like Africa provide a high target market for the cartels and organized criminal gangs that are out to sell both licit and illicit drugs to children. 
Gangs are highly organized and have well trained people to run their businesses. Apart from being well funded, they have specialized in key areas and recruited enough manpower. This enables them to control all aspects of the business without suspicion or people getting in their way. One of the scenes that the gangs have been able to control is the law and the law enforcing agencies. The use of Money, power and corruption among ranks in the police departments in many governments has worked positively for these illegal drug-peddling groups. The very people who were supposed to be protecting children and young adults are involved in the business or bribed to turn a blind eye. Research shows that many cases go unreported to the police either in fear that the police are corrupt, or the knowledge that no action would be taken due to cover-ups by the paid police, Mccoy, A. W., \& Block, A. A. (1992).

A good example of the extent of the illegal drug business corrupting the police, and how the consequences were devastating is the case of the Los Angeles Police Department. The police were so corrupt and so deep into the business that many youths and children paid with their lives. In an incident, the police attacked one man in his home, and shot him while he was holding a baby. The baby was shot in the head and died instantly. The circumstances of the attack were shady, but most sources speculated that the LAPD was tipped about a potential illegal drug gang member. They acted irrationally and were very ironic since most officers always implanted faked evidence on victims in a crime scene and carried the illegal drugs retrieved for their own benefit. Such bizarre and illogical acts of corruption by the police could cost more than we might dare not imagine. There is need for police reform and careful scrutiny and follow up of all cases reported by victims, especially children.

Apart from corrupting the legal system, resources like money have been used to heavily invest in technology and new ways to transport drugs without detection. One of the ways devised is use of schoolchildren. Most people would never suspect a child as young as 7-15 years from school as to be carrying drugs for sale. Children are recruited from the streets, or from relatives, guardians and irresponsible parents. Most of the time children do not understand the danger they are facing, and even the seriousness of the crime they are committing at any point in time, Angel-Ajani, A. (2010). The smugglers use technology to track their cargos, and ensure security to their destination. Masterminds who understand security systems and their vulnerable points carefully plan the network. In one article by a leading newspaper in Illinois, there was an alleged charge that police in Columbia discovered a submarine being built, and was intended to transport drugs only. It has been evident that in some parts of Jamaica, Mexico, Columbia and other countries known for their notoriety in narcotics trafficking to have invested in planes, choppers and expensive cars for the purpose of transporting children, drug and especially young girls, against their own will who would be used in the networks United States (2007).

Narcotics network is spread all over the world, but Africa is emerging as one of the leading continents in drug abuse by children. Coupled with the fact that, in Africa, there are low levels of education and literacy, high number of child abuse cases, high number of neglected children and street children, and the highest ranking in poverty statistics, children are extremely vulnerable, even their parents are willing to trade them for a living due to unemployment. In South Africa, it is estimated that 5\% of children under the age of 15 years are alcohol dependent, among other drug abuse cases. The most vulnerable group is street children, who are introduced to drugs and sex at a very tender age. I some parts of Africa like Kenya, Ethiopia, Ivory Coast, Nigeria and Cameroon, children are introduced to drugs due to social pressures, vulnerability of children, socio-economic problems among other factors. Some of the people who introduce them to drugs are friends, family members, schoolmates, and acquaintances. Among the drugs most commonly used by children in Africa include cannabis, cocaine, mandrax, heroine, cigarettes, alcohol, ecstasy, glue sniffing, dagga and many others, Angel-Ajani, A. (2010). 
In the United Kingdom, young people using drugs lack information on the harmful effects of most of the drugs they use. Most youth interviewed quoted that they either used drugs for fun, relaxation, relieving stress, adventure, or just excitement and happiness. Over ten percent of the under age group using drugs in the U.K had no knowledge of the negative effects on health that narcotics could cause. In Russia and surrounding parts of Europe, an estimated two million used drugs in 1998, United States (2007).Amongst these, a third of them were children. In Belarus, the number of people using drugs was closely associated with people infected with HIV/AIDS. An estimated $87 \%$ of the people infected with the disease were drug users. This shows that the risk of diseases like cancer, HIV and other terminal diseases increases with the use of drugs. Imagine the future would be like if all these children are using drugs right from such a tender age. Diseases and death are most likely to affect many youths and adults who are today's children, unless an intervention is made quickly.

\section{GLOBAL DRUG TRAFFICKING AND RELEVANCE OF CONTROL}

The demand for cocaine, heroin and other illicit drug has increased in the world. This increases the need for more drug trafficking business for people looking to sell and buy illegal drugs. The effect becomes destabilized economies, corruption of high rates and a disturbed youth in a country. Cannabis is the most traded drug ion the world, with its leading producers being Afghanistan and Colombia. Cocaine too is majorly grown in Peru, Colombia, and Bolivia. This means that the business is regionalized and most notorious in such countries. This, therefore, means that routes for transporting the drugs from their point of origin to other parts of the world have to be created. Before, the largest route had been through the United States. However, the plan changed since the Asian and European markets opened up to the trade, United States (2007).

Drug trafficking of illicit drugs and narcotics needs to be controlled for so many reasons. First of all, the drugs are a public health hazard and a threat to lives of many people not counting children. In 2010 alone, between 99,000-253,000 people were estimated to have died from use of illegal drugs. Unstable political measures and monetary self-interests drive and perpetuate the trade. If not stopped, a lot of harm could be done to governments.

\section{CONCLUSION}

The narcotic trade is one of the most widespread illicit trades in the world. This business, which can more or less referred to as organized crime, has claimed the lives of many people through the health-associated effects or confrontations among gangs or law enforcement agencies. The efforts to stop this trade can only be fruitful through international cooperation and ensuring that impunity is ironed out in various governments.

Legislation all over the world has been enacted to prevent narcotic trade in the world. However, there has been little achievement since issues like lack of awareness, corruption, and lack of international cooperation by some nations in the world. The narcotic trade is no doubt, one of the world's most serious problems, with the trade having spread to literally all the countries in the world.

The frustrations that many governments, law enforcement agencies, and the United Nations face in stopping the illicit trafficking of drugs is due to the complex nature of the problem. There are so many variables in play, where controlling all of them is most likely to be a futile effort. Poverty, corruption, illiteracy, moral degradation, unemployment, low levels of education among others are just some of the variables the stakeholders have to control to effectively stop this trade. 


\section{ACKNOWLEDGEMENTS}

I am very much humbled by the valuable support coupled with constructive criticism that I received from my Professor / Rodica Milena Zaharia,phD , Academy of Economic Studies, Bucharest ,Department of International Business and Economics. which has enabled me to learn a lot in my academic endeavors.

\section{REFERENCES}

Angel-Ajani, A. (2010), Strange trade: the story of two women who risked everything in the international drug trade, Berkeley, CA, Seal Press.

Bate, R. (2008), Making a killing: the deadly implications of the counterfeit drug trade, Washington, D.C., AEI Press.

Blanchard, C. M. (2009), Afghanistan narcotics and U.S. policy. New York, Nova Science Publishers, http://search.ebscohost.com/login.aspx?direct $=$ true\&scope $=$ site $\& \mathrm{db}=$ nlebk\&db=nlabk\&AN=352739.

Cozic, C. P. (1996), Gangs: opposing viewpoints, San Diego, CA, Greenhaven Press.

Cuban American National Foundation (U.S.) (1983), Castro's narcotics trade, Washington, D.C., Cuban-American National Foundation.

Duyne, P. C. V., \& Levi, M. (2005), Drugs and money: managing the drug trade and crime-money in Europe, London, Routledge.

Feiling, T., \& Feiling, T. (2010), Cocaine nation: how the white trade took over the world, New York, Pegasus Books.

Eisenlohr, L. E. S. (1934), International narcotics control, London, G. Allen \& Unwin ltd.

Godoy, A. S. (2013), Of medicines and markets: intellectual property and human rights in the free trade era.

Great Britain (1974), The opium trade 1910-1941, Wilmington, Del, Scholarly Resources.

Halpern, S. (1971), The international narcotics trade and its relation to the United States: report of Special Study Mission, Washington, U.S. G.P.O.

Hawkes, N. (1988), The international drug trade, Vero Beach, FL, Rourke Enterprises.

International Narcotics Control Board (1978), Estimated world requirements of narcotic drugs in, New York, United Nations.

Mabry, D. J. (1989), The Latin American narcotics trade and U.S. national security, New York, Greenwood Press.

Mccoy, A. W., \& Block, A. A. (1992), War on drugs: studies in the failure of U.S. narcotics policy, Boulder, Westview Press.

Mcdermott, R. N. (2002), Border security in Tajikistan: countering the narcotics trade? [Camberley, Surrey], Conflict Studies Research Centre, Royal Military Academy Sandhurst.

Narcotics Anonymous World Services (2008), Narcotics anonymous, Van Nuys, Narcotics Anonymous World Services, Incorporated.

Nelson, B. F. (1999), Drug control update on U.S.-Mexican counternarcotics efforts: statement of Benjamin F. Nelson, Director, International Relations and Trade Issues, National Security and International Affairs Division, before the Caucus on International Narcotics Control, U.S. Senate, Washington, D.C. (P.O. Box 37050, Washington, D.C. 20013), The Office.

O'Callaghan, S. (1969), Damaged baggage: the white slave trade and narcotics trafficking in the Americas, London, Hale.

Pacella, J. A. (1986), Controlled substance cross reference index: DEA base drug code, generic names, common trade names, Washington, D.C., U.S. Dept. of Justice, Drug Enforcement Administration, Office of Diversion Control.

Shinn, J., \& Dobbins, J. (2011), Afghan peace talks a primer, Santa Monica, CA, RAND, http://www.rand.org/content/ dam/rand/pubs/monographs/2011/RAND_MG1131.pdf.

Steinberg, D. I. (2010), Burma/Myanmar: what everyone needs to know, Oxford, Oxford University Press.

Steinberg, M. K., Hobbs, J. J., \& Mathewson, K. (2004), Dangerous harvest: drug plants and the transformation of indigenous landscapes, Oxford, Oxford University Press. 
Trocki, C. A. (1999), Opium, empire, and the global political economy: a study of the Asian opium trade, 1750-1950, London, Routledge.

United States, \& Halpern, S. (1972), The international narcotics trade and its relation to the United States, Washington, U.S. Govt. Print. Off.

United States (1977), Opium production, narcotics financing and trafficking in Southeast Asia: Asian survey: a report of the Select Committee on Narcotics Abuse and Control, April 7-20, 1977, Ninety-fifth Congress, first session, Washington, U.S. Govt. Print. Off.

United States (1986), Eastern Hemisphere narcotics, Washington, D.C., Central Intelligence Agency.

United States (2000), United States assistance options for the Andes: hearing before the Senate Caucus on International Narcotics Control and the Subcommittee on International Trade of the Committee on Finance, United States Senate, One Hundred Sixth Congress, second session, February 22, 2000, Washington, U.S. G.P.O.

United States (2007), International methamphetamine trafficking: hearing before the Subcommittee on International Economic Policy, Export and Trade Promotion and Subcommittee on Western Hemisphere, Peace Corps and Narcotics Affairs of the Committee on Foreign Relations, United States Senate, One Hundred Ninth Congress, second session, Wednesday, June 21, 2006, Washington, U.S. G.P.O. 